\title{
FIRST RECORD OF MONODONTIDAE (CETACEA, ODONTOCETI) IN THE MEDITERRANEAN BASIN FROM THE PLIOCENE SANDS OF ARCILLE (GROSSETO, TUSCANY, ITALY)
}

\author{
Fabio Pesci, Alberto Collareta (으, Chiara Tinelli \& Giovanni Bianucci (1) \\ Dipartimento di Scienze della Terra, Università di Pisa, via Santa Maria 53, 56126 Pisa (Italy); fabio.pesci@alice.it
}

KEYWORDS:

Monodontidae;

Pliocene;

Mediterranean Basin.

\section{Bullet-Points Abstract}

- MSNUP I17602 represents one of the few monodontid skull of early Pliocene age worldwide.

- This discovery testifies the presence of a monodontid taxon in the Mediterranean Basin.

- The fossil skull shares several characters with the skull of both extant monodontid genera.

- Past monodontid species seems to have been adapted to subtropical climate conditions.

\section{INTRODUCTION}

Extant monodontids (Cetacea: Odontoceti: Monodontidae) are cold-water toothed whales that inhabit the Artic, the North Atlantic, and the North Pacific Oceans. The family includes two extant species: $\mathrm{Mo}$ nodon monoceros Linnaeus, 1758 and Delphinapterus leucas (Pallas, 1776), commonly known as narwhal and beluga, respectively. The fossil history of Monodontidae is still scanty. Indeed, only two extinct species of monodontids are known to date, namely Denebola brachycephala Barnes, 1984 from the upper Miocene Almejas Formation (Isla Cedros, Mexico), and Bohaskaia monodontoides Vélez-Juarbe \& Pyenson, 2012 from the lower Pliocene Yorktown Formation (Virginia, USA). In 2013, an odontocete neurocranium was recovered from the lower Pliocene sandstones exposed in the Arcille succession (Grosseto Province, Tuscany, Italy) (Fig. 1). Thanks to the abundance of recent findings of marine vertebrate skeletons, and owing to their remarkable state of preservation, this site is now regarded as a genuine Pliocene marine Fossil-Lagerstätte (Tinelli et al., 2012; Tinelli, 2013).

\section{Materials ANd Methods}

The odontocete partial skull from Arcille is currently stored at the Museo di Storia Naturale dell'Università di Pisa (MSNUP) with accession number I17602. The list of the other odontocete skulls observed for the current study include 7 Delphinapterus leucas (MACUP AC3674; MLSUF 868; MSNUP C276; MSNUP C277; MZUN Z315; MZUN Z324; MZUN Z1013); 8 Monodon monoceros (MACUB A4216; MACUP
AC3151; MACUP AC3488; MCSNT 773; MLSUF 870; MSNB 1387; MSNUP C274; MSNUP C275).

\section{Institutional abbreviations}

MACUB, Museo di Anatomia Comparata dell'Università di Bologna; MACUP, Museo di Anatomia Comparata dell'Università di Pavia; MCSNT, Museo Civico di Storia Naturale di Trieste; MZUF, Museo "La Specola" Università di Firenze; MSNB, Museo di Scienze Naturali di Bergamo "E. Caffini"; MSNUP, Museo di Storia Naturale dell'Università di Pisa; MZUN, Museo zoologico dell'Università degli Studi di Napoli "Federico II".

\section{Discussions ANd Conclusions}

MSNUP I17602 is referred to Monodontidae owing the presence of a medial exposure of the maxillae anterior and lateral to the external bony nares [a synapomorphy of monodontids according to Muizon (1988)]. This fossil represents the first fossil occurrence of the family Monodontidae in the Mediterranean Basin. When compared with extant and extinct monodontid species, MSNUP I17602 exhibits a mosaic of characters. It shares with Denebola brachycephala, Delphinapterus leucas, and Monodon monoceros: an almost subvertical supraoccipital; a sub-circular outline of the external bony nares. It shares with Bohaskaia monodontoides and $M$. monoceros: a rounded elevated vertex; a V-shaped anterior margin of the medial exposure of the maxillae between the premaxillae. It shares only with $D$. leucas: the anteroposterior elongation of the nasals (thus differing from the oval-sha-

Corresponding author email: fabio.pesci@alice.it

How to cite: Pesci et al. (2018). First record of Monodontidae (Cetacea, Odontoceti) in the Mediterranean Basin from the Pliocene sands of Arcille (Grosseto, Tuscany, Italy). Fossilia, Volume 2018: 37-39. https://doi.org/10.32774/FosRepPal.20.1810.123739 


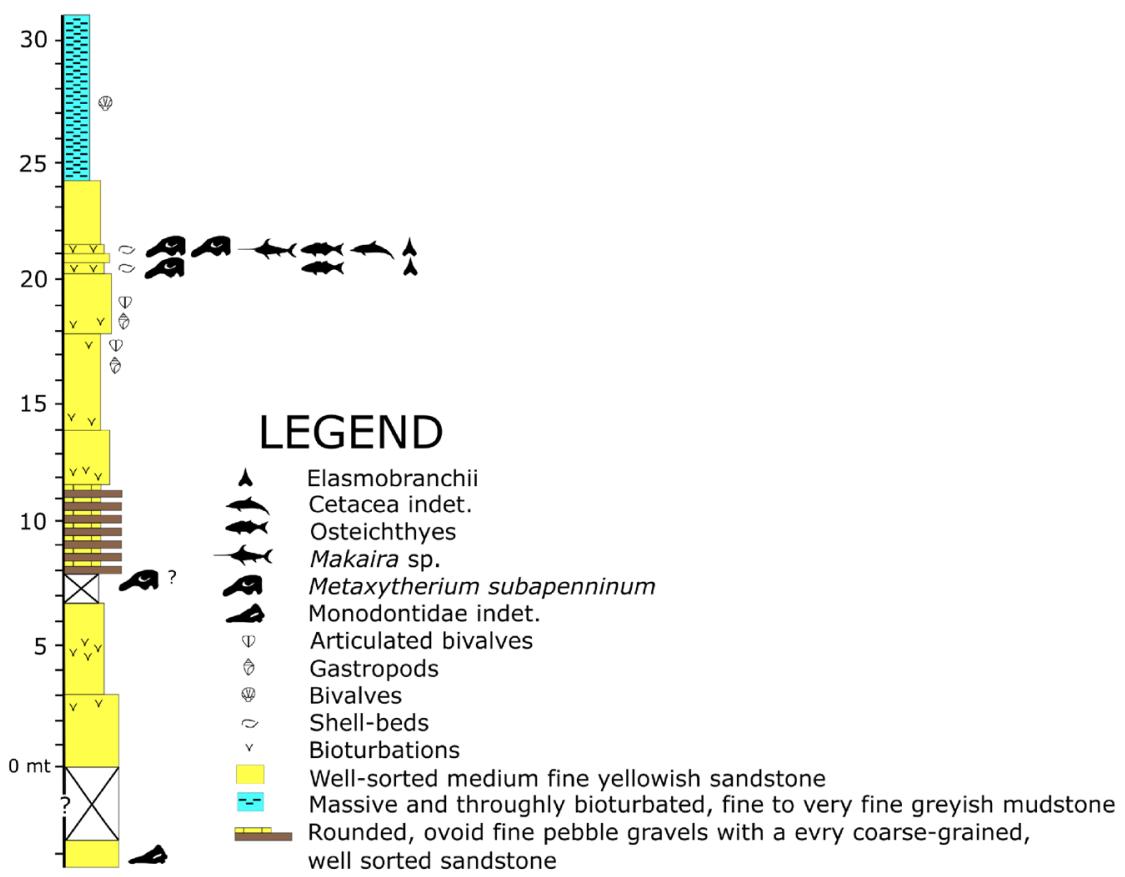

Fig. 1. Measured stratigraphic sections exposed at Arcille. Modified after Tinelli (2013).

ped nasals of $M$. monoceros and $B$. monodontoides and from the chevron-shaped ones of $D$. brachycephala); the squamosal-parietal suture that runs at half of the height of the temporal fossa; the transversely narrow and almost vertical plate of the presphenoid; the posterior end of the premaxillae taking place at about mid-length of the external bony nares (in $M$. monoceros the premaxillae almost reach the nasals, whereas in B. monodontoides and $D$. brachycephala their posterior end is placed far more anterior); and the vertex includes both the nasal and frontal bones. It shares only with M. monoceros: the swollen condition of the premaxillary sac fossae; the more posterior position of the premaxillary foramina; the arc-like disposition of the left anterior dorsal infraorbital foramina; the well-developed crest on the plate of the presphenoid. Moreover, a complete characterization of MSNUP I17602 highlights the presence of some autapomorphies that prevent any possible attribution of this specimen to the four monodontid genera known to date. These characteristics include: the depression of the premaxillae in front of the premaxillary sac fossae; the constriction of the medial exposure of the maxilla between the premaxillae just posterior to the anterior end of the external bony nares; the lateral expansion of the left premaxilla anterior to the left premaxillary foramen; the very small size of the external bony nares; the triangular nasals (which are even more slender and posteriorly elongated than in D. leucas). Considering the subtropical climate conditions of the Mediterranean Sea during the early Pliocene (Bianucci et al., 2009; Prista et al., 2015; Dominici et al., 2018), the finding of MSNUP I17602 supports the hypothesis of an ancestral adaptation of Monodontidae to warm climate conditions followed by a dispersion to high-latitude environments which ultimately led to the origin of the modern monodontid genera.

\section{REFERENCES}

Barnes L. G. (1984). Fossil Odontocetes (Mammalia: Cetacea) from the Almejas Formation, Isla Cedros, Mexico. PaleoBios, 42:321-343.

Bianucci G., Sorbi S., Vaiani S. C. \& Landini W. (2009). Pliocene marine mammals from Italy: a systematic and stratigraphic overview. International Conference on Vertebrate Palaeobiogroprahy, Abstract book, 9-12.

Dominici S., Danise S. \& Benvenuti M. (2018). Pliocene stratigraphic paleobiology in Tuscany and the fossil record of marine megafauna. Earth-Science Reviews, $176: 277-310$

Linnaeus C. (1758) - Systema Naturae per regna tria naturae, secundum Classes, Ordines, Genera, Species, cum characteribus, differentiis, synonymis, locis. Tomus I, 10th edition: Holmiae, Laurentius Salvius, Stockholm, Sweden, $824 \mathrm{p}$.

Muizon C. (1988). Les relations phylogénétiques des Delphinida (Cetacea, Mammalia). Annales de Paléontologie, 74 (4): 159-227.

Pallas P. S. (1776). Reise durch verschiedene Provinzen des Russischen Reichs. Kayserliche Academie der Wissenschaften, St. Petersburg, 3:1-454.

Prista G., Agostinho R. \& Cachão M. (2015). Observing the past to better understand the future: a synthesis of the Neogene climate in Europe and its perspectives on present climate change. Open Geosciences, 5 (7): 65-83.

Tinelli C. (2013). Marine vertebrates from Pliocene shell beds from Tuscany (Italy): prospecting, taphonomy, palaecology and systematic palaeontology. 195pp. Unpublished PhD Dissertation, Università degli studi di Pisa, Pisa, Itay.

Tinelli C., Ribolini A., Bianucci G., Bini M. \& Landini W. 
(2012). Ground penetrating radar and palaeontology: The detection of sirenian fossil bones under a sunflower field in Tuscany (Italy). Comptes Rendus Palevol, 11: 445454.

Vélez-Juarbe J. \& Pyenson N. D. (2012). Bohaskaia mono- dontoides, a new monodontid (Cetacea, Odontoceti, Delphinoidea) from the Pliocene of the western North Atlantic Ocean. Journal of Vertebrate Paleontology, 32 (2): 476- 484 .

Manuscript received 6 July 2018

Received after revision 28 September 2018

Accepted 2 October 2018 